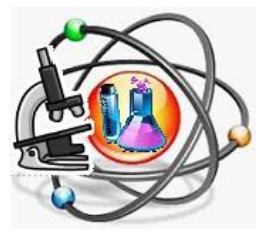

\title{
Profile of Basic Student Teaching Skills through Online Learning Models Using Peer Assessment on Microteaching Lectures
}

Profil Keterampilan Dasar Mengajar Mahasiswa melalui Model Pembelajaran Daring Menggunakan Peer Assessment Pada Perkuliahan Microteaching

\author{
Ika Nurani Dewi ${ }^{* 1}$, Sumarjan ${ }^{2}$ \\ ${ }^{1}$ Fakultas Sains Teknik dan Terapan, Universitas Pendidikan Mandalika, Indonesia \\ ${ }^{2}$ Fakultas Pertanian, Universitas Mataram, Indonesia
}

The purpose of this study was to determine the profile of the basic teaching skills of biology education students during microteaching lectures through an online learning model using peer assessment. This type of research is a qualitative descriptive study. The subjects of this study consisted of 17 prospective biology teacher students in the 6th semester of the 2019/2020 academic year. The technique of collecting data through observation uses a research instrument for assessing basic teaching skills, which is filled by lecturers and peers. Data analysis techniques include data reduction, data display and conclusions. The observed teaching skill indicators consist of 8 components. The research results obtained are the skills of opening and closing learning, explaining skills, questioning skills, discussion guiding skills, and class management skills are in the skilled category, the skills to provide reinforcement and the skills to make variations are in the fairly skilled category, while the skills to use learning media are in the less skilled category. Overall, the basic teaching skills of biology education students have improved during the microteaching exercise using peer assessment.

ISSN 25409859 (online) Edited by:

Noly Shofiyah

${ }^{*}$ Correspondence

Ika Nurani Dewi

ikanuranidewi@ikipmataram.ac.id

Received:07-04-2021

Accepted: 20-05-2021

Published: 30-05-2021

Citation:

Dewi INand Sumarjan (2021) Profile of Basic Student Teaching Skills through Online Learning Models

Using Peer Assessment on

Microteaching Lectures.

Science Education Journal (SEJ).

5:1.
Keywords: Basic Teaching Skill; Microteaching; Peer Assesmet

Tujuan dari penelitian ini adalah untuk mengetahui profil keterampilan dasar mengajar mahasiswa pendidikan biologi pada saat perkuliahan microteaching melalui model pembelajaran daring menggunakan peer assessment. Jenis penelitian ini adalah penelitian deskriptif kualitatif. Subjek penelitian ini terdiri dari 17 mahasiswa pendidikan biologi semester VI tahun akademik 2019/2020. Teknik pengumpulan data melalui observasi menggunakan instrumen penelitian berupa rubrik penilaian keterampilan dasar mengajar, yang diisi oleh dosen pengampu mata kuliah dan teman sejawat. Teknik analisis data meliputi reduksi data, display data dan kesimpulan. Indikator keterampilan mengajar yang diamati terdiri atas 8 komponen. Berdasarkan 8 indikator tersebut diperoleh hasil yaitu keterampilan 
membuka dan menutup pembelajaran, keterampilan menjelaskan, keterampilan bertanya, keterampilan membimbing diskusi, dan keterampilan mengelola kelas berada pada kategori terampil, keterampilan memberikan penguatan dan keterampilan mengadakan variasi berada pada kategori cukup terampil, sedangkan keterampilan menggunakan media pembelajaran berada pada kategori kurang terampil. Secara keseluruhan keterampilan dasar mengajar mahasiswa pendidikan biologi mengalami peningkatan selama latihan microteaching dengan menggunakan peer assessment.

Kata Kunci: Keterampilan Dasar Mengajar; Microteaching; Peer Assesmet 


\section{PENDAHULUAN}

Seorang pendidik dan pengajar yang kompeten harus memiliki kemampuan, pengetahuan, keterampilan, sikap dalam melaksanakan tugas. Menurut Undang-undang No 14 Tahun 2005 tentang guru dan dosen, menjabarkan kompetensi tersebut mencangkup kompetensi pedagogik, kepribadian, sosial dan profesional. (Wijarini and Ilma. (2017)) menjelaskan kompetensi profesional meliputi pengkajian kecakapan bidang studi yang telah dimiliki untuk berkontribusi dalam terlaksananya mekanisme pembelajaran, kompetensi sosial berhubungan dengan kemampuan pendidik/pengajar untuk berkomunikasi dengan siswa, orangtua/wali serta masyarakat sekitar, dan kompetensi kepribadian berkaitan dengan personalitas sebagai tenaga pendidik/pengajar (Siswanto. (2010)). Kompetensi guru merupakan salah satu aspek yang berdampak terhadap meningkatnya prestasi belajar siswa, sehingga seorang guru harus memiliki kualitas metode mengajar, penguasaan dan pengelolaan materi, penampilan dan kepribadian disebut sebagai keterampilan mengajar (Siswanto. (2010)). Keterampilan dasar mengajar adalah kompetensi mengajar dalam mengelaborasikan konsep, terkait dengan materi pembelajaran dengan sejumlah keterampilan yang bersifat fundamental. Keterampilan dasar mengajar melibatkan sudut pandang yang lebih luas, contohnya pembinaan perilaku, emosional, budi pekerti, budaya dan nilai-nilai. Oleh sebab itu, keterampilan dasar mengajar berpengaruh terhadap kualitas pendidikan.

Guru yang mampu menguasai dan mengimplementasikan keterampilan dasar mengajar membuat aktivitas belajar mengajar di kelas dapat terlaksana dengan baik (Siswanto. (2010)) (Kristiana and Magister. (2018)). Penguasaan dan pengimplementasian keterampilan dasar mengajar berperan penting dalam membangun iklim lingkungan belajar yang kondusif untuk mendukung kegiatan belajar mengajar (Antika and Haikal. (2019)). Situasi belajar yang kondusif mampu menumbuhkan dan mendorong siswa untuk melaksanakan proses belajar lebih optimum. Keterampilan dasar mengajar bermanfaat agar mahasiswa calon guru biologi mampu melaksanakan proses pembelajaran yang kreatif, imajinatif, efektif, dan efisien (Agustina and Saputra. (2017)). Mahasiswa sebagai calon guru sepatutnya mengetahui dan memahami beberapa dasar-dasar keterampilan dalam mengajar. Relevansi keterampilan dasar mengajar dengan hasil belajar, diperkuat oleh hasil penelitian (Atikah, Solihatin, et al. (2013)) yang mengungkapkan keterampilan dasar yang baik berpengaruh signifikan terhadap hasil belajar siswa. Keterampilan dasar mengajar merupakan jenis kecakapan yang aplikatif, sehingga harus diasah dengan latihan yang dilakukan secara sistematis melalui prosedur yang terkontrol, salah satunya adalah melalui latihan microteaching.

Supriadi menjelaskan microteaching adalah salah satu model pelatihan implementasi mengajar dalam skala mikro untuk mengembangkan keterampilan mengajar (Aprilia and Susilo. (2014)) (Asril. (2015)). Microteaching membantu mahasiswa mendapatkan pengalaman profesional dan memungkinkan mereka untuk melengkapi pemahaman teori belajar, menerapkan pengetahuan teoritis dan mengembangkan kompetensi mahasiswa sebagai persiapan mengajar agar terampil dalam mengajar di kelas (Aprilia and Susilo. (2014)), (Aydin. (2013)), (Luzywati. (2015)). Mata kuliah microteaching wajib ditempuh oleh mahasiswa pendidikan biologi di semester 6 dan merupakan mata kuliah prasyarat mahasiswa ketika akan melaksanakan PPL (Praktik Pengalaman Lapangan) di sekolah. Menurut (Aprilia and Susilo. (2014)) mahasiwa calon guru yang belum menguasai kompetensi dengan baik cenderung mengalami kesulitan bersosialisai di sekolah tempat melakukan praktik. Capaian pembelajaran mata kuliah microteaching diantaranya mahasiswa dapat memahami dan mengaplikasikan konsep keterampilan dasar mengajar, kajian kurikulum, perancangan, pengelolaan, pendekatan, model, media, serta assesment evaluasi pembelajaran. Pada mata kuliah microteaching mahasiswa dibekali wawasan keterampilan dasar mengajar serta mengimplementasikan praktek mengajar secara langsung dalam skala kecil. (Mulyatun. (2014)) menyebutkan indikator keterampilan mengajar yang harus dikuasai oleh pendidik profesional meliputi keterampilan; 1) menyusun skenario, 2) membuka dan menutup pelajaran, 3) menjelaskan materi, 4) bertanya, 5) memberikan penguatan, 6) menggunakan media, 7) mengadakan variasi, 8) membimbing diskusi, 9) melakukan penilaian, dan 10) mengelola kelas.

Sesuai dengan Surat Edaran Nomor 4 Tahun 2020 tentang pelaksanaan kebijakan Pendidikan dalam masa emergensi penularan virus COVID-19, proses perkuliahan microteaching mahasiswa semester VI jurusan pendidikan biologi tahun akademik 2020/2021 dilaksanakan melalui pembelajaran daring. Mahasiswa berinteraksi dengan dosen menggunakan aplikasi e-learning UNDIKMA, dan aktivitas praktek mengajar mereka direkam dalam bentuk video. Sistem penilaian menggunakan peer assessment, yaitu cara memberikan nilai hasil belajar yang berpusat pada siswa. Teknik penilaian ini diterapkan untuk mengevaluasi kemampuan non kognitif siswa, yaitu keterampilan dasar mengajar mahasiswa melalui latihan microteching. Dengan adanya teknik penilaian peer assessment mahasiswa memiliki kemampuan untuk menilai dan mengevaluasi teman lainnya yang berada pada kelas dan subyek dan pelajaran yang sama (Juhanda. (2017)). Peer assessment dapat digunakan untuk membangun dan mengembangkan kemampuan siswa, memverifikasi dan berpikir kritis mengenai prosedur pembelajaran yang dilaksanakan (Muslich. (2014)). Dengan adanya sistem penilaian peer assessment diharapkan dapat membentuk kompetensi dasar mahasiswa ke arah kemampuan dasar mengajar. Sistem penilaian tersebut mengatasi kelemahan sistem penilaian microteaching sebelumnya, yaitu penilaian yang dilakukan masih sebatas penilaian secara formal dan kurang memberikan informasi yang mendalam mengenai keterlaksanaan pembelajaran dan kompetensi ketercapaian mahasiswa. Sependapat dengan (Sauma, Susilaningsih, et al. (2017)) bahwa peer assesment untuk penilaian formatif meningkatkan efektivitas penilaian. Dengan menggunakan teknik penilaian peer assesment dalam pembelajaran daring 
merupakan inovasi pendidikan untuk menjawab tantangan akan keterbatasan instrumen belajar.

Tujuan dari penelitian ini adalah untuk memperoleh informasi tentang profil keterampilan dasar mengajar mahasiswa pendidikan biologi menggunakan peer assessment pada mata kuliah microteaching. Penelitian ini diharapkan dapat digunakan sebagai acuan dalam melakukan perbaikan dan peningkatan kemampuan keterampilan dasar mengajar, serta menyiapkan guru masa depan yang kompeten dan berkualitas.

\section{METODE PENELITIAN}

Penelitian ini merupakan penelitian kualitatif dengan analisis secara eksploratif. Metode triangulasi digunakan bertujuan untuk memaparkan keterampilan dasar mengajar mengajar mahasiswa berdasarkan sumber data yang ditemukan melalui observasi dan catatan tertulis. Sampel yang digunakan dalam penelitian ini terdiri dari 17 mahasiswa program studi pendidikan biologi semester VI. Penelitian dilaksanakan selama 6 bulan (1 semester perkuliahan). Teknik analisis data yang digunakan melalui reduksi data, display data dan kesimpulan. Teknik pengambilan data yang dilakukan adalah observasi menggunakan instrumen lembar penilaian keterampilan dasar mengajar. Instrumen penilaian keterampilan mengajar telah divalidasi secara empirik pada taraf signifikasi $5 \%$ semua item dinyatakan valid dengan koofisien reliabilitas 0.64 dalam kategori tinggi. Dosen dan mahasiswa memberikan penilaian berdasarkan rubrik keterampilan dasar mengajar meliputi 8 indikator. Skor yang diberikan dalam rentang $0-3$. Analisis data dilakukan dengan menjumlahkan skor di setiap masing-masing sub indikator dengan rumus, skor yang diperoleh dikalikan 100 dibagi dengan skor maksimum. Kriteria nilai yang diperoleh menggunakan kriteria aspek kualitas menurut Riduwan (2011) dikonversi dengan kategori 85-100 (sangat terampil); 70-84 (terampil); 55-69 (cukup terampil); 40-54 (kurang terampil); $<39$ (sangat kurang terampil)

\section{HASIL DAN PEMBAHASAN}

Mata kuliah microteaching dilaksanakan dalam situasi terbatas, yaitu secara daring melalui aplikasi e-learning. Hal ini dilakukan mengingat adanya pendemi Covid-19. Pada pertemuan pertama sampai dengan pertemuan ke-enam dengan durasi pembelajaran kurang lebih 50 menit, mahasiswa belajar tentang pemahaman ilmu dari materi keterampilan dasar mengajar. Dosen memberikan reinforcement skill dengan tujuan agar apa yang diperoleh mahasiswa tersebut nantinya benar-benar bermanfaat dengan baik. Pertemuan ke-tujuh sampai dengan ke-duabelas, mahasiswa tampil latihan mengajar mandiri, dalam arti mahasiswa diberikan keleluasaan menyusun skema pembelajaran dan melaksanakan praktek mengajar sebagai latihan pertama. Aktivitas latihan mengajar direkam dalam bentuk video. Setelah latihan pertama, dosen dan teman sejawat mengamati rekaman video dan diberikan saran, kritik dan penilaian berdasarkan rubrik keterampilan dasar mengajar. Selanjutnya, setiap mahasiswa merencanakan pembelajaran kembali berdasarkan saran dari teman sejawat dan bimbingan dari dosen pengampu mata kuliah yang juga direkam (latihan kedua). Penggunaan video dalam pelaksanaan microteaching dapat mempermudah pengamatan terhadap aktivitas mahasiswa dalam melakukan praktek mengajar.

Keterampilan mengajar yang diukur dalam penelitian ini meliputi: keterampilan membuka dan menutup pembelajaran, keterampilan menjelaskan, keterampilan bertanya, keterampilan memberikan penguatan, keterampilan menggunakan media pembelajaran, keterampilan mengadakan variasi, keterampilan membimbing diskusi, dan keterampilan mengelola kelas. Data keterampilan dasar mengajar mahasiswa diperoleh dari instrumen lembar pengamatan keterampilan dasar mengajar. Hasil penilaian keterampilan dasar mengajar mahasiswa Pendidikan Biologi disajikan dalam Tabel $\underline{1}$.

\section{[Table 1 about here.]}

Hasil penelitian menunjukkan keterampilan membuka pelajaran dan menutup pelajaran dalam kategori terampil. Hal ini terlihat di awal pembelajaran sebagian besar mahasiswa calon guru telah menyampaikan tujuan pembelajaran dan membangkitkan rasa ingin tahu dengan cara memberikan pertanyaan. Tujuan utama kegiatan membuka pembelajaran selain untuk mengkondisikan siswa agar memiliki motivasi saat melaksanakan aktivitas pembelajaran juga untuk memberikan acuan terhadap tujuan dan materi belajar yang akan dicapai (Hakim, Yudiyanto, et al. (2020)). Dalam pelaksanaan latihan microteaching penampilan pertama banyak mahasiswa yang terlihat kesulitan dalam memberikan apersepsi. Hal ini disebabkan karena mereka belum menyesuaikan materi dengan logika berpikir peserta didik SMP/SMA, sehingga mengalami kesulitan untuk membuat keterkaitan antara materi yang dipelajari dengan pengetahuan dan pengalaman yang dikuasai oleh siswa. Sesuai dengan pendapat (Agustina and Saputra. (2017)) bahwa kekurangan pada aktivitas membuka pelajaran adalah dalam melakukan apersepsi. Pada penampilan kedua beberapa mahasiswa calon guru melakukan suatu aktivitas untuk menarik perhatian siswa dengan memperlihatkan objek yang berkaitan dengan materi pembelajaran. Pada saat menutup pelajaran, mahasiswa meninjau kembali penguasaan materi peserta didik dengan menyampaikan rangkuman inti pelajaran, namun sebagian besar tidak melaksanakan evaluasi sebagai bagian dari remedial dan pengayaan. Dengan demikian dapat dinyatakan bahwa mahasiswa calon guru telah terampil membuka pelajaran, namun masih membutuhkan latihan untuk keterampilan menutup pelajaran.

Keterampilan menjelaskan pelajaran merupakan keterampilan esensial yang wajib dikuasai oleh seorang guru. Makna menjelaskan menurut (Mulyatun, (2014)) adalah usaha 
menyampaikan ilmu pengetahuan dalam urutan fungsional dan terencana dengan cara mengintegrasikan materi secara sistematis. Indikator keterampilan menjelaskan berada pada kategori terampil. Berdasarkan pengamatan video rekaman pada saat latihan microteaching penampilan pertama terlihat materi yang diberikan mahasiswa calon guru telah sesuai dengan capaian pembelajaran lulusan dalam kurikulum, akan tetapi tujuan pembelajaran dari indikator belum dikembangkan dengan maksimal. Selain itu, materi pembelajaran yang disajikan oleh mahasiswa calon guru akurat secara teoritis, namun kurang dipahami karena adanya pengulangan konsep. (Yuanita. (2019)) menambahkan terdapat beberapa hal yang harus diperhatikan dalam menjelaskan suatu pelajaran, diantaranya sesuai dengan kemampuan siswa, mudah dipahami, dan tidak menggunakan istilah yang meragukan. Keterampilan menjelaskan terkait dengan rancangan guru untuk menelaah materi dan kesesuaian indikator dengan kompetensi dasar (Hakim, Yudiyanto, et al. (2020)). Tabel 1 menunjukkan bahwa pada terdapat peningkatan jumlah mahasiswa calon guru yang mencapai indikator keterampilan menjelaskan. Pada penampilan kedua, sebagian besar mahasiswa calon guru memberikan contoh penerapan konsep pembelajaran yang telah dipelajari dalam kehidupan sehari-hari. Hal ini disebabkan karena dengan adanya penilaian peer assessment mahasiswa termotivasi untuk memperbaiki hasil belajar mereka. Willey \& Gardner menjabarkan bahwa penilaian teman sejawat memberikan kesempatan kepada siswa dalam menerima umpan balik yang bermanfaat dari teman kelompok dan sebagai faktor penentu keberhasilan kelompok belajar (Muslich. (2014)).

Bertanya adalah aktivitas dalam proses pembelajaran untuk memberi motivasi kepada siswa dalam bentuk kalimat pertanyaan yang membutuhkan tanggapan (Nurlaili, (2018)). Indikator keterampilan bertanya dalam kategori terampil. Hal ini disebabkan karena ada beberapa mahasiswa calon guru yang belum mampu membuat pertanyaan yang menarik minat siswa untuk menjadi lebih aktif di dalam kelas. Berdasarkan rekaman video, mahasiswa calon guru nampak kesulitan menyusun kata sederhana saat memberikan pertanyaan. Kesulitan lain yang dihadapi yaitu mahasiswa calon guru kurang memahami langkah yang perlu diperhatikan dalam mengajukan pertanyaan. Ambarawati, (2016) menjelaskan langkah tersebut meliputi: memberikan jeda waktu untuk berpikir, menunjuk untuk memberikan respon, dan menggunakan kata-kata yang mudah dipahami sesuai dengan tingkat perkembangan peserta didik. Keterampilan bertanya berarti memberikan suatu pertanyaan kepada peserta didik pada situasi yang tepat mampu mempengaruhi perubahan perilaku menjadi lebih aktif (Wijarini and Ilma. (2017)). Dengan adanya aktivitas tanya jawab mampu menimbulkan interaksi positif antara guru dengan peserta didik.

Indikator keterampilan mengadakan penguatan berada dalam kategori cukup terampil. Penguatan diberikan setelah siswa memberikan respon berupa menjawab pertanyaan. Hasil rekaman video penampilan pertama dan kedua memperlihatkan mahasiswa calon guru kurang ekspresi dalam memberikan penguatan. Penguatan yang diberikan saat penampilan pertama latihan berupa memberikan pujian berupa kalimat ungkapan. Pada penampilan kedua, keterampilan memberikan penguatan mengalami peningkatan. Penguatan tidak lagi hanya berupa memberikan pujian, namun acungan jempol, penambahan poin dan tepuk tangan. Hal ini kemungkinan disebabkan karena dengan adanya peer assessment meningkatkan rasa percaya diri, sehingga memberikan kontribusi positif terhadap kinerja mengajar mahasiswa. Penguatan dikatakan sebagai tanggapan guru terhadap tingkah laku peserta didik dengan menggunakan ucapan maupun isyarat sehingga dapat memotivasi agar lebih bersemangat pada saat pembelajaran (Aini, Suandi, et al. (2019)).

Hasil penelitian menunjukkan bahwa keterampilan menggunakan media dalam kategori kurang terampil. Komponen indikator menggunakan media dalam mengajar memperoleh skor paling rendah dibandingkan dengan indikator lainnya. Terlihat hanya 3 mahasiswa calon guru yang menggunakan alat dan bahan sebagai penunjang pembelajaran berupa puzzle (ekosistem), beberapa jenis bunga dan daun (keanekaragaman), dan cat air (difusi/osmosis). Hal ini disebabkan karena wawasan mahasiswa calon guru dalam pemanfaatan media dan kurangnya persiapan dalam merancang proses pembelajaran masih kurang. Keterampilan menggunakan media pembelajaran adalah keterampilan memanfaatkan perangkat belajar untuk digunakan dengan tujuan memudahkan menjelaskan materi. Media merupakan segala sesuatu yang dapat menyampaikan informasi dari sumber (guru) secara terencana ke penerima (peserta didik) sehingga tercipta lingkungan belajar yang efektif dan efisien (Yuanita. (2019)). Tujuan penggunaan media dalam pembelajaran memiliki peran besar dalam meningkatkan motivasi belajar yang akhirnya berdampak pada peningkatan hasil belajar peserta didik.

Berdasarkan hasil penelitian diketahui bahwa keterampilan mengadakan variasai dalam kategori terampil. Keterampilan melakukan variasi dalam pembelajaran sangat penting diterapkan untuk mengatasi kejenuhan peserta didik dalam proses belajar mengajar. Variasi belajar dapat dilakukan dalam hal variasi suara, ekspresi wajah, gerak tubuh atau posisi saat mengajar (Lisdiana. (2019)). Variasi dalam hal ini merupakan modifikasi yang dilakukan oleh mahasiswa calon guru dalam konteks pembelajaran, yang meliputi pola interaksi dengan peserta didik, penggunaan media, dan gaya mengajar. Pada penampilan pertama mahasiswa calon guru cenderung konstan saat melakukan praktek mengajar. Hal tersebut terlihat dari kontak pandang dan gerak yang dilakukan monoton, terkesan malu-malu dalam berinteraksi dan bahan ajar yang digunakan hanya berasal dari buku ajar, Namun, pada penampilan kedua terlihat ada perbedaan. Mahasiswa menggunakan berbagai variasi dalam mengajar, diantaranya menggunakan variasi bahan ajar berupa LKS, variasi mengajar dengan mengunjungi setiap kelompok secara bergantian. Hal ini kemungkinan disebabkan saat menggunakan peer assessment, mahasiswa mengamati cara mengajar rekan mereka. Berdasarkan pengamatan tersebut, mahasiswa memikirkan dengan cermat bagaimana mereka akan mempersiapkan pelajaran microteaching mereka sendiri. Penelitian (Kurniati and Liani. (2019)) menyimpulkan jika mahasiswa calon guru mempersiapkan rancangan pembelajaran yang baik, disesuaikan dengan materi serta 
signifikan dengan kompetensi dasar, maka akan meningkatkan keterampilan melakukan variasi saat mengajar di depan kelas.

Indikator membimbing diskusi dalam kategori terampil. Keterampilan membimbing diskusi merupakan keterampilan berinteraksi yang mengikutsertakan sekelompok orang dengan tujuan untuk berbagi informasi, menarik kesimpulan atau untuk menyelesaikan masalah. Pada penampilan pertama, beberapa mahasiswa calon guru merasa gugup, karena belum terbiasa berada di depan kelas sehingga masih merasa canggung dan belum bebas berekspresi. Kekurangan tersebut berhasil diperbaiki pada latihan kedua, dapat terlihat dari peningkatan skor. Pada penampilan kedua mahasiswa calon guru nampak lebih percaya diri tentang keterampilan dan keahlian mereka sendiri. Mahasiswa calon guru terlihat membuat kelompok belajar dan pada saat diskusi berlangsung mereka mampu membimbing jalannya diskusi. Dengan adanya peer assessment mahasiswa mampu mengevaluasi hasil belajarnya sendiri. Sejalan dengan pendapat Zariski bahwa kelebihan peer assessment yaitu memotivasi peserta didik mempunyai tanggung jawab terhadap proses belajarnya, sehingga menjadi insan mandiri yang berguna untuk lifelong learning dan menstimulasi deep learning (Juhanda, (2017)).

Terkait keterampilan dasar mengajar dalam mengelola kelas merupakan keterampilan menciptakan kondisi proses belajar mengajar yang maksimal bagi peserta didik, serta mengembalikan ke situasi belajar sebelumnya apabila terjadi hambatan (Siswanto, (2010)) (Asril. (2015)). Berdasarkan data dari penerapan latihan microteaching diperoleh skor rerata keterampilan mengelola kelas sebesar 70,5 dengan kategori terampil. Hal ini terlihat dari cara mahasiswa calon guru memberikan atensi dan mampu mengelola kegiatan belajar dalam kelompok. Keterampilan mengelola kelas merupakan usaha yang dilakukan oleh guru untuk menciptakan iklim belajar yang kondusif (Agustina and Saputra (2017)). Secara keseluruhan, berdasarkan hasil analisis data, diketahui terdapat kemauan serta usaha yang dilakukan oleh mahasiswa calon guru untuk memperbaiki kekurangan-kekurangan yang ada pada latihan pertama, sehingga keterampilan dasar mengajar ketika melakukan praktek mengajar pada latihan kedua meningkat dengan cukup baik. Willey \& Gardner menjelaskan bahwa peer assesment berpengaruh positif terhadap hasil belajar siswa, yaitu dapat meningkatkan hasrat mereka untuk belajar (Muslich. (2014)). Dengan semakin banyak latihan diharapkan keterampilan dalam mengorganisasi maupun melaksanakan kegiatan belajar mengajar semakin lebih baik.

Melatihkan keterampilan dasar mengajar melalui pembelajaran microteaching secara daring dilaksanakan menggunakan aplikasi e-learning sebagai media interaksi antara dosen dan mahasiswa, sedangkan aktivitas latihan mengajar mahasiswa calon guru direkam dalam bentuk video. Dosen dan teman sejawat memberikan penilaian berdasarkan rubrik keterampilan dasar mengajar melalui rekaman video praktek mengajar. Secara keseluruhan, terdapat peningkatan keterampilan mengajar mahasiswa dari penampilan sebelumnya. Hal ini disebabkan karena adanya peer assessment yang dilaksanakan pada penampilan pertama. Mahasiswa dapat belajar tentang strategi pengajaran yang berbeda dengan mengamati praktek mengajar yang dilakukan oleh orang lain. Sependapat dengan
Benton-Kupper bahwa rekaman video berguna untuk umpan balik dan refleksi, karena selama latihan microteaching, mahasiswa mampu melihat kelebihan dan kekurangan keterampilan mengajar mereka sendiri (Bakir. (2014)). Selain itu, latihan mengajar melalui microteaching dapat menjadi sarana untuk mengembangkan keterampilan dasar mengajar mahasiswa calon guru. Hal ini didukung hasil penelitian (Agustina and Saputra (2017)) bahwa pembelajaran mikro berimplikasi pada pengembangan keterampilan dasar mengajar yang dibuktikan melalui peningkatan skor. (Deswita. (2017)) menambahkan bahwa latihan microteaching memungkinkan mahasiswa memahami peran guru, menjadi lebih interaktif selama latihan dan untuk merefleksikan kinerja mereka.

Dalam pelaksanaan pembelajaran microteaching melalui daring terdapat kekurangan, sehingga mempengaruhi hasil yang ingin dicapai. Kekurangan tersebut diantaranya kegugupan saat berada di depan kamera saat proses latihan microteaching. Penyebab lain yang mempengaruhi kinerja keterampilan mengajar mahasiswa calon guru yaitu keterbatasan media yang digunakan oleh mahasiswa. HP digunakan oleh mahasiswa sebagai media untuk menyusun video mengajar. Bagi mahasiswa yang memiliki HP kurang mendukung, seperti tampilan dan volume HP akan menjadi kendala saat proses pengambilan video, sehingga tampilan video yang dihasilkan menjadi tidak maksimal. Hal tersebut akan berpengaruh saat proses penilaian keterampilan mengajar mahasiswa yang dilakukan oleh dosen dan teman sejawat, karena tampilan gambar yang dihasilkan kurang maksimal. Faktor lingkungan belajar dan karakteristik mahasiswa menyebabkan mereka tidak dapat memperoleh hasil maksimal dengan pembelajaran online.

Latihan microteaching menggunakan peer assessment memiliki memberikan kontribusi positif untuk kinerja pengajaran mahasiswa calon guru. Banyak penelitian sebelumnya melaporkan bahwa sejumlah keterampilan mengajar dapat diajarkan melalui microteaching yang meliputi: memberikan pengenalan pelajaran, memotivasi siswa, pengelolaan kelas, mengajukan pertanyaan, memilih dan menerapkan metode dan teknik pengajaran yang tepat, menyimpulkan dan melakukan evaluasi (Agustina and Saputra. (2017)) (Ambarawati, (2016)) (Luzywati. (2015)). Bakir (2014) menjelaskan latihan laboratorium microteaching memberi mereka lingkungan yang mendukung dan aman di mana mereka dapat mencoba ide dan strategi dan menerima umpan balik yang konstruktif. (Wijarini \& Ilma (2017)) menambahkan mahasiswa yang sebelumnya telah menempuh mata kuliah microteching tidak mengalami kesulitan saat praktek mengajar di sekolah saat kegiatan PPL. Latihan microteaching dapat memberikan pengalaman yang berharga bagi mahasiswa calon guru, namun akan lebih bermanfaat lagi jika latihan microteching dilaksanakan dalam proses pembelajaran yang sesungguhnya.

\section{KESIMPULAN}

Berdasarkan hasil penelitian dan analisis data diketahui bahwa tingkat penguasaan keterampilan dasar mengajar mahasiswa calon guru melalui latihan microteaching dengan menggunakan penilaian peer assessment secara keseluruhan mengalami peningkatan. Indikator keterampilan membuka 
dan menutup pembelajaran, keterampilan menjelaskan, keterampilan bertanya, keterampilan membimbing diskusi, dan keterampilan mengelola kelas berada pada kategori terampil, keterampilan memberikan penguatan dan keterampilan mengadakan variasi berada pada kategori cukup terampil, sedangkan keterampilan menggunakan media pembelajaran berada pada kategori kurang terampil. Saran dalam penelitian ini adalah latihan microteaching lebih banyak dilakukan dalam pengalaman praktek mengajar dengan situasi dan kondisi di lingkungan sesungguhnya. Untuk mengasah keterampilan dasar mengajar, mahasiswa calon guru dapat melakukan latihan microteaching bersama di kelas yang berbeda, bukan kelas mereka sendiri.

\section{UCAPAN TERIMA KASIH}

Peneliti menyampaikan terima kasih kepada Rektor Universitas Pendidikan Mandalika, Indonesia, untuk dukungan melalui sarana infrastruktur, Dekan Fakultas Sains Teknik dan Terapan untuk motivasi, saran, dan fasilitas yang telah diberikan. Terima kasih juga ditujukan kepada Lembaga Penelitian Pengabdian kepada Masyarakat (LPPM) UNDIKMA bantuan hibah Penelitian Internal, sehingga penelitian ini dapat terlaksana dengan baik

\section{REFERENCES}

Agustina, P., \& Saputra, A. (2017). Profil Keterampilan Dasar Mengajar Mahasiswa Calon Guru Biologi pada Matakuliah Microteaching. Jurnal Bioedukatika, 5(1), 18. https://doi.org/10.26555/bioedukatika.v5i1.5670

Aini, H., Suandi, N., \& Nurjaya, G. (2019). Jurnal Pendidikan Bahasa Dan Sastra Indonesia Undiksha, 8(1), 23-32. https://doi.org/10.23887/jjpbs.v8i1.20246

Ambarawati, M. (2016). Analisis Keterampilan Mengajar Calon Guru Pendidikan Matematika Pada MataKuliah Micro Teaching. PEDAGOGIA: Jurnal Pendidikan, 5(1), 81. https://doi.org/10.21070/pedagogia.v5i1.91

Antika, L. T., \& Haikal, M. (2019). Keterampilan Mengajar Mahasiswa Calon Guru Biologi: Analisis Berbasis Gender. JPBIO (Jurnal Pendidikan Biologi), 4(2), 101-107. https://doi.org/10.31932/jpbio.v4i2.524

Aprilia, N., \& Susilo, M. J. (2014). Pengembangan Instrumen Evaluasi Pembelajaran Microteaching Berbasis Perspekti Keterampilan Dasar $\begin{array}{llll}\text { Mengajar. Jurnal } & \text { Bioedukatika, } & \text { 2(2), }\end{array}$ https://doi.org/10.26555/bioedukatika.v2i2.4121

Asril, Z. (2015). Microteaching Edisi Kedua. PT. Raja Grafindo Persada. Jakarta.

Atikah, N., Solihatin, E., \& Martono, A. (2013). Hubungan Antara Keterampilan Dasar Guru Dalam Mengajar Dengan Hasil Belajar Pkn Siswa (Studi Korelasional Di Man 3 Jakarta Pusat). Jurnal PKn UNJ Online, 1.

Aydin, İ. S. (2013). The Effect of Micro-Teaching Technique on Turkish Teacher Candidates' Perceptions ff Efficacy In Lesson Planning, Implementation, and Evaluation. Electronic Journal of Social Sciences, 12(43).

Bakir, S. (2014). The Effect of Microteaching on The Teaching Skills of PreService Science Teachers. Journal of Baltic Science Education, 13(6), 789801.

Deswita, H. (2017). Profil Tingkat Penguasaan Keterampilan Dasar Mengajar Mahasiswa Pendidikan Matematika Universitas Pasir Pengaraian. Jurnal Gantang, 2(1), 51-62. https://doi.org/10.31629/jg.v2i1.65

Hakim, N., Yudiyanto, Y., Hakiki, P. R. L., \& Soleha, S. (2020). Analisis keterampilan dasar mengajar mahasiswa tadris biologi. JPBIO (Jurnal Pendidikan Biologi), 5(1), 56-63. https://doi.org/10.31932/jpbio.v5i1.576

Juhanda, A. (2017). Optimalisasi Diskusi Kelas Melalui Peer Assessment dan Self Assessment Untuk Menilai Kemampuan Komunikasi Lisan Mahasiswa Calon Guru Biologi. 8, 1-9. 10.26418/jpmipa.v9i2.25832

Kristiana, D., Magister, D. A. M., Pendidikan, A., \& Pascasarjana, S. (2018) Keterampilan Dasar Mengajar Dalam Pembelajaranmatematika Di SMP. Jurnal Managemen Pendidikan, 13(2), 204-209. file:///C:/Users/user/Downloads/7488-18390-1-SM (3).pdf
Kurniati, T., \& Liani, U. (2019). Peningkatan Keterampilan Mengadakan Variasi Pada Mahasiswa Program Studi Pendidikan Kimia. AR-RAZI Jurnal Ilmiah, $7(1)$.

Lisdiana, A. (2019). Profil Keterampilan Sosial Siswa MTs Al-Hikmah Bandar Lampung. JIPSINDO, 6(2), 112-130.

Luzyawati, L. (2015). Profil Tingkat Penguasaan Keterampilan Dasar Mengajar Mahasiswa Calon Guru Biologi. Jurnal Pengajaran Matematika Dan Ilmu Pengetahuan Alam, 20(1), 88. https://doi.org/10.18269/jpmipa.v20i1.568

Mulyatun. (2014). Analisis keterampilan dasar mengajar mahasiswa calon guru kimia (studi pada praktik pengalaman lapangan mahasiswa tadris kimia). Jurnal Phenomenon, 4(1), 79-90.

Muslich, M. (2014). Pengembangan Model Assessment Afektif Berbasis Self Assessment dan Peer Assessment di SMA Negeri 1 Kebomas. Jurnal Kebijakan Dan Pengembangan Pendidikan, 2(2), 145. http://ejournal.umm.ac.id/index.php/jmkpp/article/view/1912/2017

Nurlaili, N. (2018). JIP: Jurnal Ilmiah PGMI, 4(1), 28-40. https://doi.org/10.19109/jip.v4i1.2270

Sauma, R. S. S., Susilaningsih, E., \& Haryani, S. (2017). Pengembangan Instrumen Penilaian Unjuk Kerja Pada Presentasi Tugas Dengan Teknik Peer Assessment. Chemistry in Education, 6(2), 22-28.

Siswanto, S. (2010). Tingkat Peguasaan Keterampilan Dasar Mengajar Mahasiswa Prodi. Pendidikan Akuntansi Fakultas Ilmu Sosial Dan Ekonomi Universitas Negeri Yogyakarta. Jurnal Pendidikan Akuntansi Indonesia, 8(2), 41-51. https://doi.org/10.21831/jpai.v8i2.953

Wijarini, F., \& Ilma, S. (2017). The Analysis of Teacher Candidates' Teaching Skill in Department of Biology Education, University of Borneo Tarakan, Through Pre-service Teaching Activities. Jurnal Pendidikan Biologi Indonesia, 3(2), 149. https://doi.org/10.22219/jpbi.v3i2.4311

Yuanita, Y. (2019). Tingkat Keterampilan Dasar Mengajar Calon Guru Sekolah Dasar Pada Perkuliahan Mikroteaching [Level of Basic Skills for Teaching Prospective Primary School Teachers at Mikroteaching Lectures]. PEDAGOGIA: Jurnal Pendidikan, $\quad 8(1), \quad 69$. https://doi.org/10.21070/pedagogia.v8i1.1952

Conflictof InterestStatement:Theauthorsdeclare that theresearch was conducted in the absence of any commercial or financial relationships that could be construed as a potential conflict of interest.

Copyright (C) 2021 Dewi and Sumarjan. This is an open-access article distributed under the terms of the Creative Commons Attribution License (CC BY). The use, distributionor reproduction in other forums is permitted, provided the original author(s) and the copyright owner(s) are credited and that the original publication in this journal is cited, in accordance with accepted academic practice. No use, distribution or reproduction is permitted which does not comply with these terms. 


\section{LIST OF TABLES}

$1 \quad$ Skor Keterampilan Mengajar Mahasiswa Pendidikan Biologi ...........................................................................................27 
TABLE 1/ Skor Keterampilan Mengajar Mahasiswa Pendidikan Biologi

\begin{tabular}{|c|c|c|c|c|c|c|c|}
\hline \multirow[t]{2}{*}{ Indikator } & \multicolumn{2}{|c|}{ Skor praktek mengajar ke- } & \multirow[t]{2}{*}{ Rerata } & \multirow[t]{2}{*}{ Kategori } & \multicolumn{2}{|c|}{$\begin{array}{c}\Sigma \text { mahasiswa mencapai indicator } \\
\text { praktek mengajar ke- }\end{array}$} & \multirow{2}{*}{$\begin{array}{c}\text { Persentasi } \\
(\%)\end{array}$} \\
\hline & 1 & 2 & & & 1 & 2 & \\
\hline$A$ & 60.4 & 84.8 & 72.6 & Terampil & 10 & 17 & 100 \\
\hline$B$ & 72.1 & 79 & 75.5 & Terampil & 13 & 17 & 100 \\
\hline $\mathrm{C}$ & 75.8 & 70.4 & 73.1 & Terampil & 9 & 17 & 100 \\
\hline$D$ & 53.3 & 65.1 & 59.2 & Cukup & 9 & 15 & 88.23 \\
\hline$E$ & 34.7 & 61.4 & 48.1 & Kurang & 3 & 10 & 58.82 \\
\hline $\mathrm{F}$ & 53.1 & 72.2 & 62.6 & Cukup & 7 & 14 & 82.45 \\
\hline $\mathrm{G}$ & 68.9 & 77.5 & 73.2 & Terampil & 11 & 15 & 88.23 \\
\hline $\mathrm{H}$ & 60.2 & 80.8 & 70.5 & Terampil & 12 & 14 & 82.35 \\
\hline
\end{tabular}

Keterangan:
A. Membuka dan menutup pembelajaran
B. Menjelaskan
E. Penggunaan media
C. Bertanya
F. Mengadakan variasi
D. Memberikan penguatan
G. Membimbing diskusi
H. Mengelola kelas 